\section{British research council jumps at gene therapy}

London. The British Medical Research Council (MRC) is pressing ahead with a commitment to stimulate gene therapy in Britain, and has named a 20-member committee of academic and industrial scientists and government officials to promote research and its application in the field.

This development follows shortly after the decision by an advisory committee to approve a second gene therapy trial, involving cystic fibrosis patients. But it coincides disappointingly with an acknowledgement by those carrying out the first trial that their efforts have so far failed to produce significant improvement in the condition of a oneyear-old girl with adenosine deaminase (ADA) deficiency.

The chairman of the MRC committee will be Peter Rigby, head of the genes and cellular controls group at the MRC's $\mathrm{Na}$ tional Institute for Medical Research. Its official terms of reference are "to give advice, resolve issues and problems, co-ordinate clinical trials and the resultant data, and encourage interaction with industry".

Two-thirds of the committee's members are scientists working in universities, charity-funded laboratories and research council institutes. Others include representatives of the drug companies Glaxo and Zeneca, and officials from the Medicines Control Agency and the Department of Health. The committee does not include independent experts in medical ethics, reflecting MRC's belief that responsibility for regulating gene therapy should rest with the Department of Health.

One of the new committee's first tasks, according to Diane McLaren, executive secretary of the MRC's molecular and cellular medicine board, will be to allocate funds for a number of university-based gene therapy centres under a government initiative on genetic approaches to human health; 27 outline proposals have been received since applications were invited earlier this year.

In contrast with the speed of MRC's move and the enthusiasm of research groups, the British government continues to drag its heels over regulatory procedures. Although it is 18 months since a committee chaired by the lawyer Sir Cecil Clothier recommended a special gene therapy advisory committee (see Nature 355, 190; 1992), the full committee is not now expected to be announced until September. But it is known that it will be chaired by Dame June Lloyd, who retired last October as Nuffield professor of child health at the University of London's Institute of Child Health, at which the ADA experiments were planned. Lloyd, a specialist in familial lipoprotein disorders, is scientific adviser to the Association of Medical Research Charities, and a member of the

\section{MRC committee}

Until the new body comes into operation, proposals for gene therapy experiments are still being assessed by the Clothier committee. At its last meeting, the committee approved a set of clinical trials planned at the Royal Brompton Hospital and St Mary's Hospital Medical School into a potential treatment for cystic fibrosis.

The final go-ahead for the experiments, which will use liposomes to transfer functioning DNA into volunteer patients through nasal inhalation, awaits detailed approval by the Medicines Control Agency. But Bob Williamson, professor of biochemistry at $\mathrm{St}$ Mary's, says the trials are expected to start "within the next few months".

A second group, based in Oxford and

Cambridge, which described earlier this year the insertion of a cystic fibrosis gene into mice bred with a defect in the gene, is also hoping to start trials on human patients before the end of the year.

Several experiments in the gene therapy of cystic fibrosis are in progress in the United States, using adenovirus vectors, but there are reports that some of these have run into difficulties related to viral pathogenicity. The British researchers hope the use of liposomes will open up a more benign route to successful treatment, answering scepticism about the viability of liposomes as an alternative to adenoviruses by suggesting that the optimal therapy may eventually turn out to be a combination of approaches.

Meanwhile, physicians at the Great Ormond Street Children's Hospital say that, despite the lack of evidence that the ADA gene replacement therapy carried out on one-year-old Carly Todd has been successful, there is still 'a possibility' that treated stem cells will develop into a new immune system for her.

David Dickson

\title{
Max Planck expands toward the east
}

Munich. The Max Planck Society (MPG) has been tipped off by the federal government that funding for five new Max Planck institutes in the former East Germany may indeed be forthcoming, the general squeeze on resources precipitated by reunification notwithstanding. Last week's meeting of the MPG senate at Trier was therefore able to endorse its plans, agreed in principle last year, to set up in the new Länder three new institutes in the natural sciences and two in the social sciences.

Uncertainties over finance have delayed the setting up of the institutes. The federal funds provided in the 1990 reunification treaty for building up research in the new Länder did not stretch as far as funding all seven institutes originally earmarked. But setting up institutes virtually from scratch has also required more time than had been predicted. Only two - the Institute for Microstructure Physics at Halle and the Institute for Colloid and Surface Science in Berlin - are so far established.

There are now signs that the federal government is willing to provide its share (half) of the costs of the five new institutes. Research minister Paul Krüger, himself an east German, is firmly committed to giving priority to initiatives in the new Länder, and is this week negotiating with finance minister Theo Waigel in preparation for the federal budget on 13 July.

The other half of the budgets of Max Planck institutes normally comes from all the German Länder, but the reunification treaty requires only the new Länder to contribute to costs for their own institutes, at least until 1995. Thus the new institutes will cost western German Länder nothing for the time being, giving the lie to complaints that the east is "draining resources" from the west. Most of the new Länder are said to be ready to sign contracts.

The new institutes include:

An institute for infection biology in east Berlin, to be established by the end of 1994 . It will eventually be housed in a new building near the Charite university clinic to be built by 1998 . It will have 100 positions, 35 for scientists, and an annual operating budget of around DM11 million (US\$7 million).

An institute for molecular plant physiology near Potsdam in Brandenburg. Work will begin in 1994, but the 90 staff (26 scientists) will move into a new building in 1998. The institute will have a budget of about DM9 million a year.

- An institute for the physics of complex systems at Dresden opens next month, and moves to a new building on the campus of the Technical University in 1998. Although small (37 positions, of which 17 will be scientists), it will be one of the few in the world dedicated to this multidisciplinary field; an extensive guest programme is planned.

Institutes for economics (Jena) and history of science (Berlin) will increase the number of Max Planck institutes in the social sciences, which have been much neglected. The new institutes are much welcomed in the east, where unemployment among scientists has been high - and confidence low - since reunification. However, all three directors so far designated are from western Germany, matching current trends (see Nature 362, 685; 1993).

But the good news has not ended. MPG says that it is considering further initiatives in the new Länder for the second half of the 1990 s.

Alison Abbott 